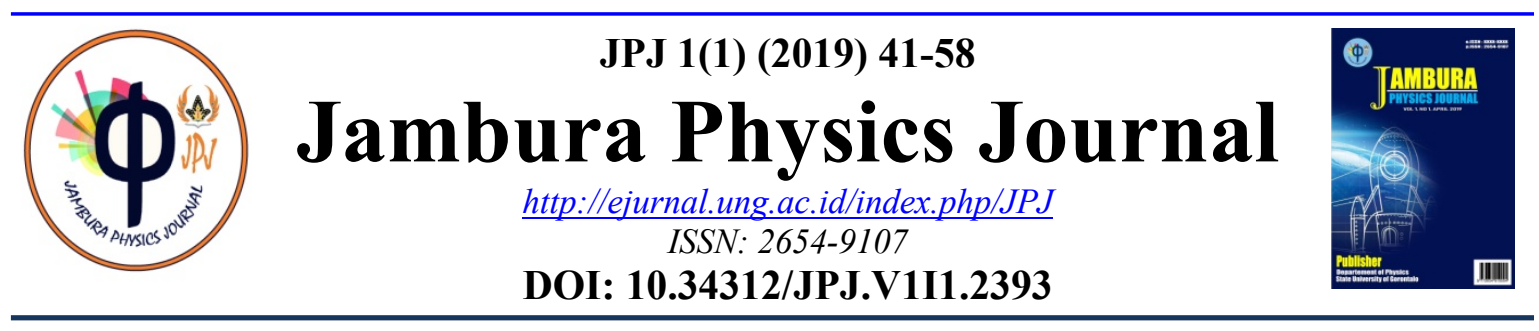

\title{
MODEL ASSESMEN PENGETAHUAN KONSEPTUAL MAHASISWA DALAM MEMECAHKAN MASALAH FISIKA
}

\author{
Yusuf. $\mathbf{M}^{1^{*}}$,Prabowo ${ }^{2}$ \\ ${ }^{1}$ Universitas Negeri Gorontalo, Gorontalo \\ ${ }^{2}$ Universitas Negeri Surabaya, Surabaya
}

Accepted: December 19 2018. Approved: April 02 2019. Published: April 292019

\begin{abstract}
Abstrak.
Berbagai macam model pembelajaran dikembangkan oleh para pengembang pendidikan. Namun kenyataannya kecakapan mahasiswa dalam memecahkan masalah masih rendah. Hal ini menunjukkan adanya masalah pada diri mahasiswa yang diduga adalah pengetahuan konseptual. Untuk mengkaji pengetahuan konseptual mahasiswa ini, maka perlu dikembangkan suatu model assesmen pengetahuan konseptual mahasiswa. Tujuan penelitian ini adalah untuk mengembangkan model assesmen pengetahuan mahasiswa dalam memecahkan masalah Fisika dan implementasinya. Penelitian termasuk penelitian pengembangan dengan menggunakan pendekatan kualitatif yaitu mengembangkan model assesmen pengetahuan konseptual mahasiswa dalam memecahkan masalah Fisika. Model assesmen yang telah dikembangkan akan diuji kevalidan oleh ahli yang kompeten. Proses penelitian ini akan dilaksanakan dengan beberapa tahap yaitu tahap pengembangan model instrumen pengetahuan konseptual mahasiswa, uji coba model assesmen. Uji lapangan dilaksanakan pada mahasiswa Program Studi Pendidikan Fisika Universitas Negeri Surabaya. Berdasarkan hasil Penelitian diperoleh model assesmen pengetahuan konseptual mahasiswa dalam memecahkan masalah Fisika. Hasil implementasi model assesmen dapat disimpulkan bahwa subjek dengan kategori akademik tinggi dapat mendefinisikan dan mengaplikasikan konsep dengan sangat baik, tetapi kurang baik dalam menunjukkan interelasi antara beberapa konsep pada pemecahan masalah. Sedangkan subjek dengan kategori akademik rendah dapat mendefinisikan konsep dengan baik, tetapi kurang baik dalam mengaplikasikan konsep fisika, serta tidak baik dalam menunjukkan interelasi antara beberapa konsep pada pemecahan masalah fisika.
\end{abstract}

Kata Kunci: Model Assesmen; Pengetahuan Konseptual; Fisika

*Alamat Korespondensi

E-mail: : andi.yusuf88@yahoo.com

Jambura Physics Journal, Vol. 1 No. 1, April 2019 


\section{Pendahuluan}

Faktor kendala kecakapan mahasiswa dalam memecahkan masalah fisika tidak hanya disebabkan oleh faktor proses perkuliahan, tetapi juga ditengarai oleh faktor dalam diri mahasiswa. Menurut Jonassen (2005) pemecahan masalah gagal karena pengetahuan mahasiswa yang diperlukan untuk memecahkan masalah kurang. Ditemukan kendala mahasiswa dalam memecahkan masalah pada penggunaan pendekatan fisika dan aplikasi konsep fisika (Yusuf, Prabowo, \& Tjipto, 2014; Yusuf \& Prabowo, 2016). Sabella \& Redish (2007) mengatakan adanya hubungan yang lemah antara pengetahuan kualitatif dan kuantitatif mahasiswa dalam memecahkan masalah.

Pengetahuan merupakan sesuatu hal yang ada dalam benak pikiran setiap orang, dan setiap orang memiliki tingkat pengetahuan yang berbeda. Pengetahuan adalah hasil bentukan seseorang sendiri. Anderson et al. (2001) membedakan jenis pengetahuan yaitu: (a) Pengetahuan faktual, (b) Pengetahuan konseptual, (c) Pengetahuan prosedural, (d) pengetahuan metakognitif. Model assesmen pengetahuan yang akan dikembangkan dalam penelitian ini adalah model assesmen pengetahuan konseptual.

Pemilihan pengetahuan konseptual dalam penelitian ini, karena pengetahuan ini yang paling urgen bagi mahasiswa dalam memecahkan masalah fisika. Pengajar fisika perlu memperhatikan penggunaan struktur pengetahuan mahasiswa karena sangat mempengaruhi kemampuannya dalam mengintegrasikan konsep fisika (Sabella dan Redish, 2007; Kennedy, 1997; Toth and Sebestyen, 2009 ). Pengetahuan konseptual lebih efektif pada diri mahasiswa dalam menjelaskan ide-ide baru dibanding dengan pengetahuan procedural (Matthews and Rittle-Johnson , 2008; Krange and Ludvigsen, 2008; Solas-Portales dan Sanjose, 2006, 2008).

Berdasarkan beberapa penjelasan di atas menjadi dasar peneliti bahwa pengetahuan konseptual mahasiswa perlu untuk dikaji dan diungkap, agar dosen mengetahui tingkatan pengetahuan yang dimiliki oleh mahasiswa. Jika pengetahuan konseptual yang dimiliki oleh mahasiswa tidak diketahui oleh dosen kemudian memberikan materi lebih tinggi dari kemampuan mahasiswa, maka akan berdampak pada ketidakberhasilan mahasiswa dalam memecahkan masalah fisika dan pengimplementasian pemecahan masalah dalam kehidupan sehari-hari.

\section{Masalah Penelitian}

Masalah dalam penelitian ini adalah bagaimanakah model assesmen pengetahuan konseptual mahasiswa dalam memecahkan masalah fisika. 


\section{Fokus Penelitian}

Penelitian hanya berfokus pada fisika dasar materi mekanika dan assesmen model pengetahuan yang dikembangkan adalah pengetahuan konseptual.

\section{Kajian Pustaka}

\section{Pengertian Pengetahuan}

Pengetahuan merupakan sesuatu hal yang ada dalam benak pikiran setiap orang, dan setiap orang memiliki tingkat pengetahuan yang berbeda. Proses pembentukan pengetahuan terjadi apabila seseorang mengubah atau mengembangkan skema yang telah dimiliki dalam berhadapan dengan tantangan, ransangan atau persoalan. Teori pengetahuan Piaget mengatakan bahwa pengetahuan tidak dapat ditransfer dari otak guru yang dianggap tahu bila mahasiswa tidak mengolah dan membentuknya sendiri.

Pengetahuan adalah hasil bentukan seseorang sendiri. Jenis pengetahuan berbedabeda berdasarkan pendapat ahli. Ferguson et al. (1990), dan De Jong \& Ferguson (1996) membedakan jenis utama pengetahuan yaitu: (a) pengetahuan situasional, (b) pengetahuan deklaratif juga disebut pengetahuan konseptual, (c) pengetahuan prosedural, dan (d) pengetahuan strategis. Anderson et al. (2001) membedakan jenis pengetahuan yaitu: (a) Pengetahuan faktual, (b) Pengetahuan konseptual, (c) Pengetahuan prosedural, (d) pengetahuan metakognitif. Pengetahuan yang akan dikaji dalam penelitian ini adalah jenis pengetahuan menurut Anderson et al. (2001) dan akan difokuskan pada jenis pengetahuan konseptual.

\section{Pengetahuan Konseptual}

Konsep adalah adalah ide atau gagasan abstrak yang digunakan untuk mengelompokkan suatu objek. Konsep tidak ada dalam dunia nyata karena konsep adalah abstraksi. Konsep hanya dapat membantu mengorganisasikan berbagai macam informasi menjadi unit-unit yang mudah ditangani. Beberapa definisi tentan konsep menurut para ahli dalam memecahkan masalah seperti sebagai berikut. Definisi konsep awal adalah "penggambaran mental, ide, atau proses". Konsep adalah ide-ide abstrak yang merepresentasikan kategori-kategori informasi atau unit-unit pengetahuan (Solso et al., 2008). Konsep adalah gagasan yang merujuk pada sebuah kelompok atau kategori dimana anggotanya sama-sama memiliki karakteristik umum (Eggen \& Kauchak, 2012). Konsep adalah satuan arti yang mewakili sejumlah objek yang memiliki ciri-ciri yang sama. 
Satuan arti adalah pengertian abstrak yang menunjukkan pada suatu aspek tertentu yang ditemukan pada suatu objek (Winkel, 2004).

Penggunaan karakteristik-karakteristik yang jelas bertujuan untuk memutuskan apakah suatu contoh termasuk dalam kategori konsep atau bukan. Biasanya, apa yang kita pikirkan tentang konsep adalah sebuah kata tunggal yang merepresentasikan gagasangagasan (Jacobsen et al., 2009). Pemahaman konsep mahasiswa dalam fisika sangat, karena dengan pemahaman konsep fisika mahasiswa mampu: (1) mengembangkan kemampuan bernalar dalam berpikir analisis induktif dan deduktif dengan menggunakan konsep dan prinsip fisika untuk menjelaskan berbagai peristiwa alam dan menyelesaian masalah baik secara kualitatif maupun kuantitatif, (2) mengembangkan pengetahuan, dan sikap percaya diri.

Pengetahuan konseptual adalah sesuatu yang diketahui tentang fakta dan definisi. Arends (1997) membedakan pengetahuan menjadi tiga jenis yaitu pengetahuan deklaratif, pengetahuan prosedural, dan pengetahuan kondisional. Sedangkan Anderson et al. (2001) memberikan batasan pengetahuan menjadi empat, yaitu: (1) pengetahuan faktual, (2) pengetahuan konseptual, (3) pengetahuan prosedural, dan (4) pengetahuan metokognisi.

Pengetahuan konseptual meliputi skema-skema, model-model mental, atau teori implisit dan eksplisit dalam model-model psikologi kognitif yang berbeda. Pengetahuan konseptual dicapai dalam dua cara, yaitu dengan membangun hubungan antara potongan informasi atau penciptaan hubungan antara pengetahuan yang ada dengan informasi yang baru saja masuk system (Hiebert and Lefevre dalam Long, 2005).

Menurut Sabella dan Redish (2007), pengetahuan konseptual merupakan bagian penting bagi mahasiswa dalam belajar memecahkan masalah fisika. mahasiswa harus mampu memahami apa masalahnya, fisika apa yang relevan, dan bagaimana menginterpretasikan hasilnya. Sedangkan menurut Haapasalo (2003) pengetahuan konseptual menunjukkan pengetahuan dan keterampilan tertentu, unsur-unsur, konsepkonsep, dan aturan (algoritma) prosedural. Begitu juga pendapat Rittle-Johnson et al., (2001) pengetahuan konseptual sebagai pemahaman implicit atau eksplisit dari prinsipprinsip yang mengatur domain dan saling keterkaitan antara unit pengetahuan dalam domain.

Pengetahuan konseptual adalah pengetahuan yang dimiliki seseorang berupa faktafakta, definisi-definisi, dan konsep-konsep (Anderson, 2001). Pengetahuan konseptual merupakan pengetahuan yang dapat membantu setiap mahasiswa saat mereka berupaya mentransfer apa yang mereka sudah pelajari pada situasi-situasi baru. Anderson et al. 
(2001) membagi pengetahuan konseptual menjadi tiga jenis yaitu: pengetahun klasifikasi dan kategori, pengetahuan prinsip-prinsip dan generalisasi, dan pengetahuan mengenai teori, model, dan struktur.

\section{Pengetahuan tentang Klasifikasi}

Klasifikasi adalah menentukan bahwa sesuatu merupakan milik ke suatu kategori. Pengetahuan tentang klasifikasi dan kategori umumnya merupakan cerminan dari bagaimana cara pakar memikirkan dan menyelesaikan masalah.Pengetahuan klasifikasi dan kategori adalah aspek penting dalam mengembangkan kecakapan dalam suatu disiplin ilmu. Pengklasifikasian informasi dan pengalaman ke dalam kategori-kategori yang tepat merupakan sebuah tanda klasik perkembangan dan pembelajaran. Aktivitas belajar mahasiswa bisa terhambat karena salah klasifikasi informasi menjadi kategari-kategori yang tidak tepat. Misalnya mahasiswa mengalami kesulitan memahami konsep-konsep dasar sains, seperti panas, cahaya, tenaga, dan listrik ketika mereka mengklasifikasikan konsep-konsep ini sebagai zat, bukan sebagai proses.

Pengklsifikasian terjadi ketika mahasiswa mengenal bahwa sesuatu milik kategori tertentu (misalnya konsep). Jadi, jika mahasiswa mempelajari klasifikasi yang benar dan kategori yang benar dapat merefleksikan perubahan konseptual dan terjadi dalam pengertian yang lebih sesuai mengenai konsep dari pada mereka hanya mempelajari definisi-definisi (kategori pengetahuan faktual). Ketika mahasiswa mulai bekerja dalam sebuah mata pelajaran dalam satu disiplin ilmu dan belajar bagaimana menggunakan peralatan-peralatan ini, maka nilai klasifikasi dan kategori akan menjadi tampak.

\section{Pengetahuan tentang Generalisasi}

Pengetahuan mengenai prinsip dan generalisasi tersusun atas klasifikasi dan kategori. Prinsip dan generalisasi cenderung mendominasi disiplin akademis dan digunakan untuk mengatasi masalah-masalah dalam disiplin ilmu. Salah satu ciri dari seorang pakar mata pelajaran adalah kemampuan untuk mengenal pola-pola yang bermakna (seperti generalisasi) dan memulai pengetahuan relevan mengenai pola-pola ini dengan sedikit upaya kognitif.

Prinsip dan generalisasi meliputi pengetahuan abstraksi (ikhtisar-ikhtisar) tertentu yang meringkas hasil observasi mengenai fenomena. Ikhtisar ini memiliki nilai terbesar dalam menggambarkan, memprediksi, atau menentukan tindakan yang relevan dan sesuai 
arah yang harus ditempuh. Prinsip dan generalisasi cenderung menjadi gagasan-gagasan yang luas yang mungkin sulit bagi para mahasiswa untuk memahami karena mahasiswa mungkin sepenuhnya dikenalkan dengan fenomena dan mereka dimaksudkan meringkas dan mengorganisasi.

\section{Pengetahuan tentang Teori}

Pengetahuan tentang teori meliputi pengetahuan mengenai prinsip dan generalisasi bersama dengan hubungan intern yang memberikan pandangan sistematis yang bulat dan jelas menyangkut fenomena yang kompleks, masalah, atau mata pelajaran. Pengetahuan ini merupakan rumusan-rumusan abstrak dan dapat menunjukkan interelasi dan susunan dari banyak detail, klasifikasi dan kategori, serta prinsip dan generalisasi yang spesifik

Pengetahuan ini meliputi pengetahuan mengenai paradigma-paradigma yang berbeda dan epistemologi-epistemologi untuk membuat pertanyaan, dan mahasiswa seharusnya tahu cara berbeda dalam mengkonseptualisasikan, mengelola dan menilai mata pelajaran. Pengetahuan mahasiswa mengenai teori akan memandu dalam mengaplikasikan pada pemecahan masalah.

\section{Metodologi Penelitian}

Metode yang digunakan adalah metode penelitian pengembangan (R\&D) dengan menggunakan pendekatan kualitatif. Pemilihan metode ini untuk mengembangkan model assesmen pengetahuan konseptual mahasiswa dalam memecahkan masalah fisika, pengimplementasian, dan pengumpulan data. Jadi metode ini akan menunjang pelaksanaan pengembangan model instrumen pengetahuan konseptual mahasiswa dalam memecahkan masalah Fisika Dasar.

Penggunaan pendekatan kualitatif karena dalam pengimplementasian model assesmen yang telah dikembangkan karena memenuhi karakteristik penelitian kualitatif. Menurut Bogdan \& Biklen (1992) terdapat lima karakteristik penelitian kualitatif yaitu: (1) bersifat naturalistik merupakan penelitian dilakukan sesuai keadaan sumber data yang sebenarnya dan peneliti merupakan instrumen utama, (2) data deskriptif yaitu data yang dikumpulkan dalam bentuk kata-kata, (3) memperhatikan proses yaitu proses lebih diperhatikan dari pada hasil, (4) bersifat induktif, dan (5) bermakna (meaning) yaitu peneliti memperhatikan apa yang disebut participant perspectives. Menurut Lincoln dan 
Guba (1985) penelitian kualitatif dilakukan pada seting alamiah atau pada konteks dari suatu entitas.

\section{Subjek Penelitian}

Penelitian dilaksanakan pada mahasiswa Program Studi Pendidikan Fisika yang memprogramkan mata kuliah Fisika Dasar. Subjek dalam penelitian ini terdiri mahasiswa dengan kemampuan akademik tinggi dan kemampuan akademik rendah. Subjek penelitian sebanyak 4 orang terdiri dari 2 orang untuk subjek dengan akademik tinggi dan 2 orang untuk subjek dengan akademik rendah.

\section{Instrumen Penelitian}

Penelitian ini akan menghasilkan model assesmen pengetahuan konseptual mahasiswa dalam memecahkan masalah fisika, sehingga intrumen yang digunakan adalah lembar validasi model assesmen pengetahuan konseptual. Model assesmen yang dikembangkan divalidasi oleh ahli, sedangkan untuk implementasi model assesmen, instrumen utamanya adalah peneliti dengan menggunakan menggunakan tes dan wawancara. Hal ini sesuai pendapat Lincoln dan Guba (1985) dalam penelitian kualitatif peneliti sebagai pengumpul data dan menginterpretasi data yang diperoleh selama penelitian.

\section{Teknik Analisis Data}

Data hasil validasi model pengembang Penelitian ini menggunakan pengujian kredibilitas data yaitu menggunakan triangulasi metode, yaitu membandingkan informasi atau data dengan metode yang berbeda (Lincoln dan Guba, 1985). Pengujian kredibitas ini dilakukan peneliti dengan cara memverifikasi antara data yang diperoleh berupa dokumen jawaban tertulis dengan hasil wawancara mendalam.

\section{Hasil Penelitian}

\section{Model Assesmen Pengetahuan Konseptual}

Hasil pengembangan model assesmen pengetahuan konseptual divalidasi oleh dua orang ahli pada bidang pendidikan fisika. Berdasarkan data hasil validasi oleh ahli diperoleh bahwa model assesmen yang dikembangkan adalah valid dengan beberapa saran dan masukan untuk perbaikan. Saran dan masukan dari ahli terdiri dari: a) perlu perbaikan pada indikator-indikator yang akan diukur pada pengetahuan tentang klasifikasi, pengetahuan tentang generalisasi, pengetahuan tentang teori; b) penentuan kategori 
penilaian antara kategori sangat baik, baik, kurang baik, dan tidak baik harus lebih diperjelas; c) harus menentukan soal atau tes yang dapat mengungkap pengetahuan klasifikasi, pengetahuan tentang generalisasi, pengetahuan tentang teori.

Tabel 1. Model Assesmen Pengetahuan Konseptual dalam Memecahkan Masalah Fisika

\begin{tabular}{|c|c|}
\hline $\begin{array}{l}\text { Aspek Pengetahuan } \\
\text { Konseptual: }\end{array}$ & Indikator \\
\hline $\begin{array}{l}\text { Pengetahuan tentang } \\
\text { Klasifikasi }\end{array}$ & $\begin{array}{l}\text { Mahasiswa mampu: } \\
\text { 1. menentukan karakteristik suatu kategori dengan benar. } \\
\text { 2. memberikan contoh pada kategori dengan benar. }\end{array}$ \\
\hline $\begin{array}{l}\text { Pengetahuan tentang } \\
\text { Generalisasi }\end{array}$ & $\begin{array}{l}\text { Abstraksi yang dipilih dijadikan dasar untuk dapat: } \\
\text { 1. menggambarkan pola-pola atau konsep yang tepat dalam } \\
\text { memecahkan masalah. } \\
\text { 2. Memprediksi, atau menentukan tindakan relevan dan sesuai arah } \\
\text { yang harus ditempuh dalam memecahkan masalah. }\end{array}$ \\
\hline $\begin{array}{l}\text { Pengetahuan tentang } \\
\text { Teori }\end{array}$ & $\begin{array}{l}\text { Jika mahasiswa mampu: } \\
\text { 1. Mendefisikan konsep } \\
\text { 2. Mengaplikasikan teori pada pemecahan masalah dengan benar, } \\
\text { 3. Menunjukkan interelasi antara beberapa konsep pada pemecahan } \\
\text { masalah. }\end{array}$ \\
\hline
\end{tabular}

Berdasarkan saran-saran dan masukan dari ahli tersebut, kemudian peneliti memperbaiki model assesmen pengetahuan konseptual ini, sehingga menghasilkan model assesmen pengetahuan konseptual mahasiswa dalam memecahkan masalah fisika seperti tabel 1 dan rubrik kategori assesmen pengetahuan konseptual dalam memecahkan masalah fisika seperti pada lampiran.

\section{Implementasi Model Assesmen Pengetahuan Konseptual}

Implementasi model assesmen pengetahuan konseptual dilakukan untuk ujicoba model assesmen ini pada pemecahan masalah fisika oleh mahasiswa melalui tes dan wawancara. Pada makalah ini hanya akan membahas data aspek pengetahuan konseptual yang ketiga yaitu pengetahuan tentang teori. Untuk memudahkan peneliti dalam menganalisis data, maka digunakan pengkodean sebagai berikut: 1) subjek pertama 01T dan kedua 02T untuk kategori akademik tinggi, 2) subjek pertama 01R dan kedua 02R untuk kategori akademik rendah, 3) kode P untuk peneliti.

Pengetahuan tentang teori oleh subjek akan diungkap dengan memberikan permasalahan konseptual sebanyak dua soal uraian berikut: Pertama: Jika benda percepatannya nol, apakah berarti kecepatan juga harus nol? Jelaskan dan berikan contoh!, Kedua: Seseorang berjalan menaiki sebuah lereng bukit setinggi $500 \mathrm{~m}$. Ia memutuskan untuk berjalan dengan lintasan berliku-liku yang jauhnya $500 \mathrm{~m}$. Bagaimana dengan energi 
dan gaya yang ia kerahkan untuk lintasan berliku-liku dibandingkan dengan mendaki bukit dengan lintasan lurus.

Jawaban tertulis yang diberikan oleh subjek dengan kategori akademik tinggi seperti yang terdapat pada gambar 1 dan 2 untuk soal pertama.

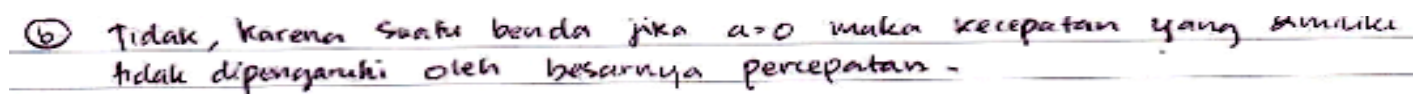

. Gambar 1 Dokumen Tertulis oleh Subjek 01T untuk soal pertama

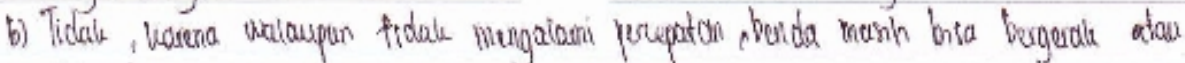
$\checkmark$ worston

Gambar 2. Dokumen Tertulis oleh Subjek 02T untuk soal pertama

Berdasarkan dokumen jawaban tertulis pada gambar 1 dan 2 menunjukkan subjek $01 \mathrm{~T}$ dan $02 \mathrm{~T}$ dapat mengaplikasikan teori pada pemecahan masalah dengan baik yaitu menjelaskan bahwa tidak selamanya percepatan nol berarti kecepatan juga harus nol. Subjek 01T dan 02T juga dapat menunjukkan interelasi antara beberapa konsep pada pemecahan masalah dengan baik yaitu menjelaskan bahwa kecepatan yang dimiliki suatu benda tidak dipengaruhi oleh besarnya percepatan benda. Namun, kedua subjek tidak memberikan contoh terhadap penjelasan yang diberikan. Hal ini menunjukkan subjek 01T dan $02 \mathrm{~T}$ dapat menggunakan pendekatan fisika yang spesifik dalam memecahkan masalah dengan baik.

Wawancara dilakukan pada subjek dengan kategori akademik tinggi untuk menggali lebih mendalam pengetahuan tentang teori yang dimilikinya. Hasil wawancara oleh subjek $01 \mathrm{~T}$ diperoleh informasi pengetahuan tentang teori sebagai berikut.

P-1 : Apa Anda sering melihat benda-benda yang bergerak?

01T-1 : Iya pak

P-2 : contohnya apa?

01T-2 : seperti mobil, sepeda, saya sendiri.

P-3 : Ok, coba jelaskan definisi gerak itu?

01T-3 : Gerak itu suatu benda yang mengalami perubahan posisi dari posisi semula ke posisi terakhir dia bergerak.

P-4 : Misalnya suatu benda bergerak dengan percepatan nol, apakah berarti juga harus kecepatan nol, coba anda jelaskan dengan contoh?

01T-4 : tidak, misalknya saat mobil bergerak dengan kecepatan tetap $10 \mathrm{~m} / \mathrm{s}$, kemudian percepatannya tidak harus sama dengan kecepatannya.

Hasil wawancara yang dilakukan terhadap subjek 02T diperoleh informasi sebagai berikut.

P-1 : pada saat anda masuk ke ruangan ini. Apakah itu termasuk gerak? 
02T-1 : iya

P-2 : apa definisi gerak itu?

02T-2 : berpindah dari suatu tempat ke tempat lain.

P-3 : ok, misalnya benda yang memiliki percepatan nol, apakah harus berarti kecepatannya juga nol? Coba jelaskan dengan contoh.

02T-3 : tidak, misalnya mobil bergerak kecepatannya $40 \mathrm{~km} / \mathrm{jam}$ itu konstan, tidak mengalami percepatan

Hasil wawancara menunjukkan subjek 01T dan 02T dapat mendefinisikan konsep yaitu gerak. Subjek juga dapat mengaplikasikan teori dan menunjukkan interelasi antara beberapa konsep pada pemecahan masalah yaitu dengan menjelaskan bahwa bila percepatan suatu benda nol tidak berarti kecepatan juga harus nol dan memberikan contoh dengan sangat baik. Hal ini menunjukkan bahwa subjek 01T dan 02T memiliki dalam pengetahuan tentang teori sangat baik pada materi gerak dan dapat menggunakan pendekatan fisika yang spesifik dalam memecahkan masalah.

Jawaban tertulis yang diberikan oleh subjek dengan kategori akademik tinggi untuk masalah yang kedua seperti pada gambar 3 dan 4. Jawaban tertulis oleh subjek 01T seperti yang tampak pada gambar 3 .

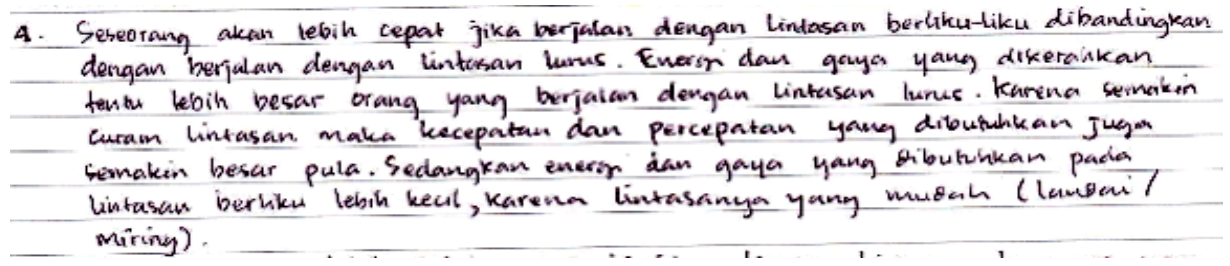

Gambar 3. Dokumen Tertulis oleh Subjek 01T untuk soal kedua

Sedangkan jawaban tertulis yang diberikan oleh subjek 02T seperti pada gambar 4 .

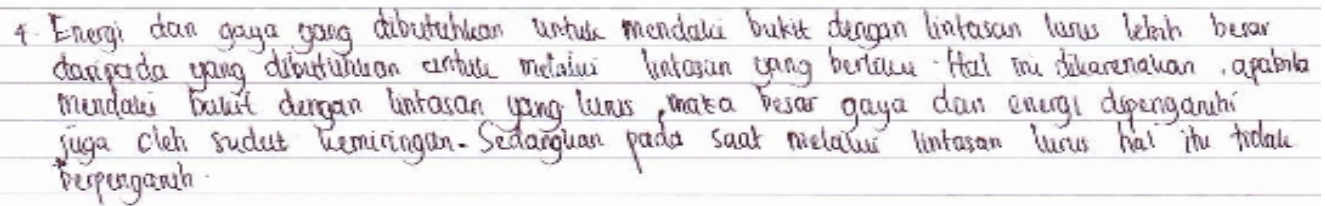

Gambar 4. Dokumen Tertulis oleh Subjek 02T untuk soal kedua

Berdasarkan dokumen jawaban tertulis pada gambar 3 dan 4 yang diberikan oleh subjek menunjukkan bahwa subjek 01T dan 02T baik dalam mengaplikasikan teori gaya pada pemecahan masalah, tetapi kurang baik dalam mengaplikasikan teori energy. Hal ini tampak subjek 01T dan 02T kurang baik dalam menunjukkan interelasi antara beberapa konsep pada pemecahan masalah karena subjek menjelaskan bahwa energi dan gaya yang dibutuhkan lebih besar pada pendakian dengan jalur lurus dibanding dengan jalur berlikuliku, seharusnya energy yang dibutuhkan antara jalur pendakian lurus dan berliku-liku adalah sama, hanya gaya yang berbeda. 
Hasil petikan wawancara yang dilakukan terhadap subjek 01T yang berhubungan dengan masalah kedua diperoleh informasi tentang pengetahuan tentang teori sebagai berikut.

P-1 : Kira-kira gaya itu apa?

01T-1 : Gaya itu tarikan atau dorongan yang menyebabkan benda bergerak.

P-2 : Misalkan anda melakukan sesuatu itu kan butuh energi. kira-kira energi itu apa definisinya?

01T-2 : Energi itu usaha untuk melakukan sesuatu.

P-3 : Misal Anda mau naik bukit yang tingginya 100 meter. ada dua jalur yang bisa di lalui yaitu lurus dan berliku-liku dengan jarak yang lebih besar. Bagaimana energi dan gaya yang dibutuhkan untuk bisa sampai ke puncak pada dua jalur tersebut?

01T-3 : Pada saat melalui jalan menanjak itu gaya yang dibutuhkan besar dan energi yang dibutuhkan juga besar namun jaraknya singkat. Kemudian saat berlikuliku gaya dan energi yang dibutuhkan sedikit, namun butuh waktu yang lama.

Sedangkan hasil wawancara yang dilakukan terhadap subjek 02T diperoleh informasi sebagai berikut.

P-1 : Definisi gaya itu apa?

02T-1 : Gaya itu sesuatu menyebabkan benda bergerak.

P-2 : Lanjut, kalau berjalan kita butuh energi. Definisi energi itu apa?

02T-2 : suatu yang tidak bisa dimusnahkan.

P-3 : Oke, misalnya Anda naik bukit setinggi 50 meter dengan jalan kaki. kalau mau lurus waktunya pendek atau sedikit, tapi mau berliku-liku waktunya panjang. Kira-kira bagaimana gaya dan energi yang dibutuhkan dengan jalan lurus dan berliku-liku sampai di puncak?

02T-3 : Energi dan gaya lebih banyak dibutuhkan ketika saya menanjak bukitnya dengan lurus. Sedangkan kalau berjalan berliku-liku energi dan gayanya kecil.

Petikan hasil wawancara menunjukkan subjek 01T dan 02T dapat mendefinisikan konsep yaitu gaya dan energi. Subjek 01T dan 02T dapat mengaplikasikan teori gaya pada pemecahan masalah, tetapi kurang baik dalam mengaplikasikan teori energi. Berdasarkan hasil wawancara terlihar subjek 01T dan 02T kurang baik dalam menunjukkan interelasi antara beberapa konsep pada pemecahan masalah yakni menjelaskan bahwa energy dan gaya yang dibutuhkan pada pendakian dengan jalur yang lurus lebih besar dibandingkan dengan jalur yang berliku-liku, seharusnya energy yang dibutuhkan antara jalur pendakian lurus dan berliku-liku adalah sama, tetapi gayanya yang berbeda.

Berdasarkan hasil analisis jawaban tertulis dan analisis wawancara oleh subjek dengan kategori akademik tinggi, dilakukan pengujian keabsahan data melalui triangulasi metode. Pengetahuan tentang teori yang dimiliki oleh subjek dengan kategori tinggi yang diterima keabsahan keterlaksanaanya disajikan berikut: (1) subjek $01 \mathrm{~T}$ dan $02 \mathrm{~T}$ dapat mendefinisikan konsep dengan sangat baik, (2) subjek 01T dan 02T dapat mengaplikasikan 
teori gerak, gaya, dan energi dengan baik, (3) subjek 01T dan 02T kurang baik dalam meunjukkan interelasi antara beberapa konsep dalam memecahkan masalah.

Subjek dengan kategori akademik rendah juga mengerjakan masalah konseptual pertama yang diberikan pada subjek dengan kategori akademik tinggi. Dan jawaban tertulis yang diberikan oleh subjek 01R seperti pada gambar 5 .

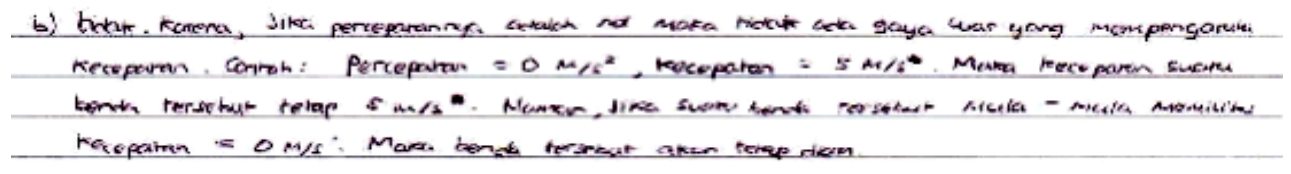

Gambar 5. Dokumen Tertulis Subjek 01R untuk soal pertama

Sedangkan jawaban tertulis yang diberikan oleh subjek 02R dapat dilihat pada gambar 6 .

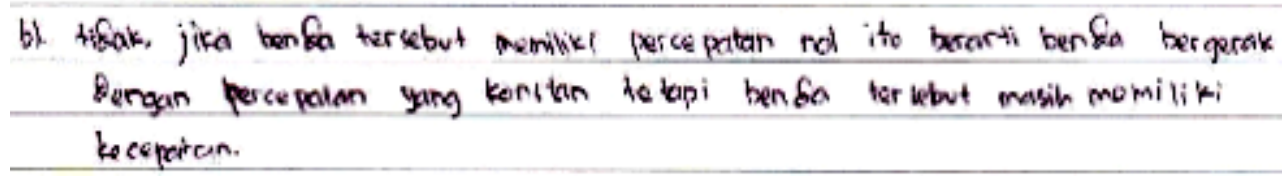

Gambar 6. Dokumen Tertulis Subjek 02R untuk soal pertama

Berdasarkan gambar 5 dan 6 dokumen jawaban tertulis yang diberikan menunjukkan subjek 01R dan 02R dapat mendeskripsikan informasi dari masalah, sehingga dapat mengaplikasikan teori pada pemecahan masalah dengan sangat baik yaitu kecepatan dan kecepatan. Penggunaan pendekatan fisika yang spesifik juga baik, sehingga Subjek 01R dan $02 \mathrm{R}$ dapat menunjukkan interelasi antara beberapa konsep pada pemecahan masalah yaitu dengan menunjukkan bahwa bila percepatan suatu benda itu nol, maka tidak selamanya kecepatan juga harus nol. Di samping itu subjek 01R juga menjelaskan dengan memberikan contoh dengan baik. Sedangkan subjek 02R tidak dapat memberikan contoh.

Petikan wawancara yang telah dilakukan terhadap subjek 01R untuk pengetahuan tentang teori sebagai berikut.

P-1 : ya, masuk ke ruang ini anda bergerak, goyang-goyang juga bergerak. Definisi dari gerak itu apa?

01R-1 : Definisi gerak itu .....................ee melakukan proses perpindahan.

P-2 : Bila benda bergerak dengan percepatan nol, apakah harus juga kecepatan nol?

01R-3 : tidak

P-3 : Contohnya apa?

01R-3 : seperti ini jarum jam yang kecepatannya tetap berarti percepatannya nol. Sedangkan hasil petikan wawancara yang telah dilakukan terhadap subjek 02R untuk pengetahuan tentang teori sebagai berikut.

P-1 : Tiap hari Anda bergerak ya?

02R-1 : iya pasti pak.

$\mathrm{P}-2 \quad$ : Apa definisi gerak?

02R-2 : Gerak itu dari posisi A ke posisi B. 
P-5 : Ok, kalau misalnya percepatan suatu benda adalah nol, apakah harus juga kecepatan nol?

02R-5 : tidak

P-6 : contohnya apa?

02R-6 : mobil yang bergerak dengan kecepatan konstan.

Berdasarkan hasil petikan wawancara menunjukkan subjek 01R dan 02R mendeskripsikan informasi dari masalah yang diberikan. Ini terlihat subjek 01R dan 02R dapat mendefisikan konsep gerak. Subjek 01R dan 02R juga dapat mengaplikasi teori pada pemecahan masalah yaitu pada kecepatan dan percepatan. Selain itu subjek dapat menunjukkan interelasi beberapa konsep pada pemecahan masalah yang menunjukkan bahwa bila percepatan benda nol tidak selamanya juga kecepatan nol. Di mana subjek dapat memberikan contoh pada mobil yang bergerak konstan itu percepatannya nol. Hal ini menunjukkan penggunaan pendekatan fisika yang spesifik oleh subjek 01R dan 02R adalah baik.

Masalah konseptual kedua juga diberikan pada subjek dengan kategori akademik rendah. Dan jawaban tertulis yang diberikan oleh subjek 01R seperti yang terdapat pada gambar 7.

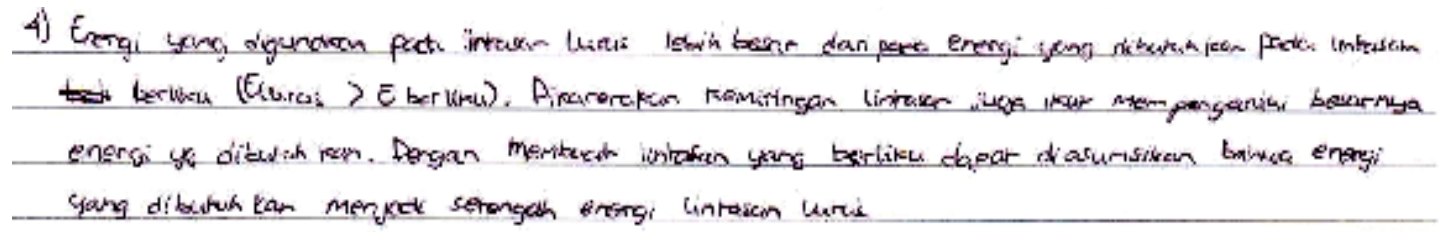

Gambar 7. Dokumen Tertulis Subjek 01R untuk soal kedua

Sedangkan jawaban tertulis yang diberikan oleh subjek 02R untuk soal kedua seperti terlihat pada gambar 8 .

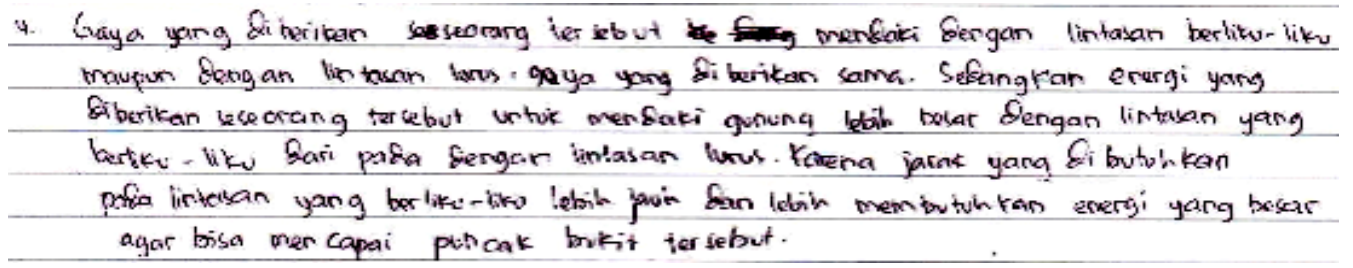

Gambar 8. Dokumen Tertulis Subjek 02R untuk soal kedua

Berdasarkan gambar 7 dan 8 tentang jawaban tertu lis yang diberikan oleh subjek 01R dan 02R menunjukkan bahwa subjek tidak dapat mendeskripsikan informasi dari masalah yang diberikan, sehingga tidak dapat mengaplikasikan teori pada pemecahan masalah dengan baik. Selanjutnya, subjek 01R dan 02R juga tidak dapat menunjukkan interelasi antara beberapa konsep pada pemecahan masalah dengan baik. Subjek 01R dan 02R tidak dapat menunjukkan interelasi antara energi dan gaya pada masalah pendakian 
dengan jalur yang berbeda. Hal ini menunjukkan penggunaan pendekatan fisika yang spesifik kurang baik dalam memecahkan masalah.

Petikan wawancara yang telah dilakukan pada subjek 01R adalah sebagai berikut.

P-1 : ok, Gaya itu macam-macam seperti gaya dorong, gaya gravitasi. Definisi gaya itu apa?

01R-1 : gaya itu yang saya tahu massa kali percepatan.

P-5 : Berikutnya, kalau Anda melakukan sesuatu selalu membutuhkan energi. Apa itu energi?

01R-5 : energi itu sebuah tindakan yang dilakukan (diam).

P-6 : Lanjut, misalnya Anda naik gunung tingginya 200 meter. Ada dua jalur bisa dilewati yaitu lurus dan berliku-liku dengan jarak panjang. Bagaimana gaya dan energi yang dibutuhkan untuk bisa sampai ke puncak?

01R-6 : Untuk energinya lebih besar energinya yang lurus, dan untuk gayanya sama. Sedangkan hasil petikan wawancara yang telah dilakukan pada subjek 02R adalah sebagai berikut.

P-1 : Tadi anda menyebutkan gaya gravitasi, yang saya tanyakan, gaya itu apa?

02R-1 : gaya itu sesuatu yang diberikan pada benda.

P-2 : Kalau kita bekerja butuh energi. Apa itu energi?

02R-2 : energi itu sesuatu yang dikeluarkan menghasilkan gaya.

P-3 : Misalkan Anda naik gunung setinggi 200 meter. ada dua pilihan yaitu satu lurus langsung naik ke atas, dan satu melingkar dengan menempuh jarak sekian. Bagaimanakah energi dan gaya yang dibutuhkan untuk bisa naik ke puncak?

02R-3 : lebih berat energi dan gaya yang dibutuhkan kalau jalan lurus. kalau yang lurus itu gaya yang lebih besar, terus kalau berliku-liku energinya yang besar.

Hasil petikan wawancara menunjukkan subjek 01R dan 02R kurang baik mendeskripsikan informasi dari masalah, sehingga subjek 01R dan 02R tidak dapat mengaplikasikan teori pada pemecahan masalah. Hal ini dipengaruhi oleh subjek 01R tidak dapat mendefinisikan konsep gaya dan energi dengan baik. Subjek 01R dan 02R juga tidak dapat menunjukkan interelasi antara beberapa konsep pada pemecahan masalah yaitu tidak dapat menunjukkan interelasi antara energi dan gaya yang dibutuhkan pada masalah pendakian yang menggunakan jalur yang berbeda.

Berdasarkan hasil analisis jawaban tertulis dan analisis wawancara oleh subjek dengan kategori akademik rendah, dilakukan pengujian keabsahan data melalui triangulasi metode. Pengetahuan tentang teori yang dimiliki oleh subjek dengan kategori rendah yang diterima keabsahan keterlaksanaanya disajikan berikut: (1) subjek 01R dan 02R dapat mendefinisikan konsep dengan baik, (2) subjek 01R dan 02R dapat mengaplikasikan teori gerak, tetapi kurang baik mengaplikasikan teori gaya dan energi, (3) subjek 01R dan 02R kurang baik dalam meunjukkan interelasi antara beberapa konsep dalam memecahkan masalah. 


\section{Pembahasan}

Penelitian ini bertujuan mengembangkan model assesmen pengetahuan konseptual mahasiswa dalam memecahkan masalah fisika dan implementasinya. Berdasarkan hasil dan validasi dari ahli ditemukan model assesmen pengetahuan konseptual sebagai berikut: (1) pengetahuan tentang klasifikasi dengan indicator mahasiswa mampu menentukan karakteristik suatu kategori dan memberikan contoh; (2) pengetahuan tentang generalisasi dengan indicator mahasiswa dapat menggambarkan pola-pola atau konsep yang tepat dalam memecahkan masalah, memprediksi atau menentukan tindakan relevan dan sesuai arah yang harus ditempuh dalam memecahkan masalah; (3) pengetahuan tentang teori dengan indicator mahasiswa mampu mendefinisikan konsep, mengaplikasikan teori pada pemecahan masalah dengan benar, dan menunjukkan interelasi antara beberapa konsep pada pemecahan masalah.

Berdasarkan deskripsi dan hasil analisis data, maka pengetahuan tentang teori yang dimiliki oleh subjek dengan kategori akademik tinggi ditemukan bahwa subjek sangat baik dalam mendefinisikan konsep gerak, gaya, dan energi. Mendeskripsikan informasi dari masalah yang baik memudahkan subjek dalam mengaplikasikan teori pada pemecahan masalah yaitu subjek dapat mengaplikasikan bahhwa bila percepatan benda nol tidak harus kecepatan juga nol. Subjek dengan akademik tinggi kurang baik mengaplikasikan teori pada gaya dan energi yang dibutuhkan pada pendakian dengan menggunakan jalur yang lurus dan berliku-liku, sehingga subjek kurang baik dalam menunjukkan interelasi antara beberapa konsep pada pemecahan masalah (T-3) yaitu dengan menunjukkan bahwa jalan yang berliku-liku dan lurus pada pendakian dibutuhkan energi dan gaya yang sama, seharusnya energi yang dibutuhkan dalam pendakian adalah sama antara jalur lurus dengan jalur berliku-liku, tetapi gayanya yang berbeda yaitu gaya lebih besar dibutuhkan pada jalur yang lurus dibandingkan dengan jalur yang berliku-liku.

Temuan ini sesuai dengan temuan Solso (1987) bahwa melalui cara memberikan contoh-contoh dari suatu konsep disertai definisinya dapat lebih mempermudah seseorang membentuk prototipe, daripada cara menunjukkan definisi dan disertai pernyataan penjelas hubungan di antara atribut-atribut kritis. Menurut pendapat Soedjadi (2007) bahwa mahasiswa yang dapat membedakan contoh dan bukan merupakan ciri yang telah memahami konsep. Menurut Winkel (2004) mahasiswa yang dapat menghubungkan konsep-konsep satu sama lain atau mengkombinasikan satau dengan lainnya adalah mahasiswa yang mengerti dengan konsep atau teori. 
Hasil analisis data pengetahuan tentang teori yang dimiliki oleh subjek dengan kategori akademik rendah ditemukan bahwa subjek dapat mendefisikan konsep gerak, tetapi tidak dapat menefisikan gaya dan energi dengan baik. Subjek dengan kategori akademik rendah dapat mengaplikasikan teori gerak yaitu dengan menjelaskan bahwa bila percepatan benda nol tidak harus kecepatan juga nol. Namun, subjek tidak dapat mengaplikasi teori pada pemecahan masalah tentang energi dan gaya yang dibutuhkan pada pendakian dengan menempuh berliku-liku dengan jalur yang lurus. Subjek mengungkapkan bahwa energi dibutuhkan pada pendakian yang lurus lebih besar, sedangkan gaya yang dibutuhkan sama untuk kedua lintasan. Hal ini menunjukkan bahwa subjek dengan kategori akademik rendah tidak dapat menggunakan pendekatan konsep pada pemecahan masalah (PM-2), sehingga subjek tidak dapat menunjukkan interelasi antara beberapa konsep pada pemecahan masalah (T-3).

Berdasarkan beberapa penjelasan dari temuan di atas, maka tampak bahwa subjek dengan akademik sedang dan rendah tidak baik dalam menunjukkan interelasi antara beberapa konsep pada pemecahan masalah. menurut Winkel (2004) diperlukan pemahaman tentang teori yang baik untuk bisa mengkombinasikan antara beberapa konsep. Pengetahuan konseptual memuat relasi-relasi (antara konsep Fisika) dan keterkaitan relasi tersebut dengan konsep (fisika). Menurut Soedjadi (2007) untuk memperjelas konsep, maka diperlukan suatu pembatasan yang disebut definisi. Definisi itu ungkapan yang memberi batasan dari suatu konsep. Jika dikaitkan dengan temuan peneliti di atas, maka jelas bahwa subjek yang kurang baik dalam mengaplikasikan teori dalam memecahkan masalah karena subjek tidak dapat mendefinisikan konsep dengan baik.

\section{Kesimpulan}

Berdasarkan latar belakang masalah dan hasil penelitian dapat disimpulkan bahwa diperoleh model assesmen pengetahuan konseptual mahasiswa dalam memecahkan masalah fisika sebagai berikut: (1) pengetahuan tentang klasifikasi dengan indicator menentukan karakteristik suatu kategori dan memberikan contoh; (2) pengetahuan tentang generalisasi dengan indicator menggambarkan pola-pola atau konsep yang tepat dan memprediksi atau menentukan tindakan relevan dan sesuai arah yang harus ditempuh dalam memecahkan masalah; (3) pengetahuan tentang teori dengan indicator mendefinisikan konsep, mengaplikasikan teori pada pemecahan masalah dengan benar, dan menunjukkan interelasi antara beberapa konsep pada pemecahan masalah. 
Hasil implementasi model assesmen pengetahuan konseptual mahasiswa dapat disimpulkan bahwa subjek dengan kategori tinggi dapat mendefinisikan konsep dengan sangat baik, mengaplikasikan teori dengan baik, tetapi kurang baik dalam menunjukkan interelasi antara beberap konsep pada pemecahan masalah gaya dan energi. Sedangkan subjek dengan kategori akademik rendah memiliki dapat mendefinisikan konsep dengan baik, dapat mengaplikasikan teori gerak dengan baik, tetapi kurang baik dalam mengaplikasikan teori gaya dan energi, sserta kurang baik dalam dalam menunjukkan interelasi antara beberap konsep pada pemecahan masalah gaya dan energi.

\section{Referensi}

Anderson, L., Krathwohl, D.R., Airasian, P., Cruikshank, K., Mayer, R., Pintrich, P., Raths, J., Wittrock, M. 2001. A Taxonomy for Learning, Teaching, and Assessing: a revision of Bloom's Taxonomy of education Objectives. New York: Addison Wesley Longman.

Arends, R.I. 1997. Classroom Instruction and Management. New York: McGraw Hill Companies, Inc.

Bogdan, R. C. \& Biklen. S.K. 1992. Qualitative research in Education: An Introduction to Theory and Method. (two edition). Boston: Allyn and bacon.

De Jong, T., \& Ferguson- Hessler, M. G. M. 1996. "Types and Qualities of Knowledge". Educational Psychologist,7, pp. 105-113.

Eggen, P., \& Kauchak, D. 2012. Strategie and Models for Teching: Teaching Content and Thinking Skills, sixth Edition. Terjemahan satrio Wahono. Jakarta: PT. Indeks.

Ferguson- Hessler, M. G. M. \& De Jong, T. 1990. "Studying Physics texts: differences in study processes between good and poor performers". Cognition and Instruction, 7, pp. 41-54.

Haapasalo, L. 2003. "Linking procedural and conceptual mathematical knowledge in technology-based learning". Brno, Czech Republic: The Mathematics Education into the $21^{\text {st }}$ Century Project Proceedings of the International Conference The Decidable and the Undecidable in Mathematics Education, September 2003.

Jacobsen, D., Eggen, P., \& Kauchak, D. 2009. Methods for Teaching: Promotion Student Learning in K-12 Classrooms. Terjemahan Achmad Fawaid \& Khoirul Anan. Yogyakarta: Pustaka Pelajar.

Jonassen, D.H. 2005. "Tools For Representing Problems and the Knowledge Required to Solve Them". S.-O. Tergan and T. Keller (Eds): Knowledge and Information Visualization, LNCS 3426, pp. 82-94.

Kennedy, M. 1997. Defining Optimal Knowledge for teaching Science and Mathematics. NISE: University of Wisconsin-Medison.

Krange, I., and Ludvigsen, S. 2008. "What does it mean? Students' procedural and conceptual problem solving in a CSCL environment designed within the field of science education". Computer-Supported Collaborative Learning (2008) 3.pp. 25-51.

Lincoln, Y.S. \& Guba, E.G. 1985. Naturalistic Inquiry. New Delhi: SAGE Publications.

Long, C. 2005. "Maths Concepts in Teaching: Procedural and Conceptual Knowledge". Pythagoras 62. Pp. 59-65. 
Matthews, P., Rittle-Johnson, B. 2008. "In Pursuit of Knowledge: Komparing Selfexplanations, Concepts, and Procedures as Pedagogical Tools". Journal of Experimental Child Phychology xxx. Pp. 1-21.

Rittle-Johnson, B., Siegler, R. S., \& Alibali, M.W. 2001. "Developing Conceptual Understanding and Procedural Skill in Mathematics: an iterative processs". Journal of Educational Psychology. Vol 93 pp. 346-362.

Sabella, M., \& Redish, E. 2007. "Knowledge activation and organization in physics problem-solving". Jurnal Organization of Knowledge. Pp. 1-14.

Soedjadi, 2007. Masalah Konstekstual sebagai Batu Sendi Matematika Sekolah. Surabaya: Pusat Sains dan Matematika Sekolah UNESA.

Solaz-Portolés, J. J. \& Sanjosé, V. 2006. ¿Podemos predecir el rendimiento de nuestros alumnos en la resolución de problemas? Revista de Educación, 339, pp. 693-710.

Solaz-Portolés, J.J. and Sanjosé, V. 2008. "Types of knowledge and their relations to problem solving in science: directions for practice". Sísifo. Educational Sciences Journal, 06, pp. 105-112.

Solso, R.L. 1987. Cognitive Psychology. Boston: Allyn And Bacon, Inc.

Solso, R.L., Maclin, O.H., Maclin, M.K. 2008. Cognitive Psychology, Eight Edition. Boston: Pearson Educational.

Toth, Z., Sebestyen, A. 2009. "Relationship between Students' Knowledge Structure and Problem-Solving Strategy in Stoichiometric Problems based on the Chemical Equation". Eurasian Journal of Physics and Chemistry Education Vol 1 No. 1. pp.820.

Winkel, W.S. 2004. Psikologi Pengajaran. Yogyakarta: Media Abadi.

Yusuf, M., Prabowo, Prastowo, T. 2014. "Pengembangan Instrumen dalam Memecahkan Masalah Fisika Dasar". Prosiding Seminar Nasional Kimia \& Pendidikan Kimia UNG 2014 hal. 227-234.

Yusuf, M., Prabowo. 2016. Deskripsi Problem Solving Skill Peserta Didik Pada Pembelajaran Fisika. Prosiding Seminar Nasional pada Pertemuan Ilmiah XXX HFI Jateng \& DIY, UKSW Salatiga 2016. 